\title{
BMJ Global Health Undernutrition, obesity and governance: a unified framework for upholding the right to food
}

\author{
Jesse B Bump
}

To cite: Bump JB.

Undernutrition, obesity and governance: a unified framework for upholding the right to food. BMJ Glob Health 2018;3:e000886. doi:10.1136/ bmjgh-2018-000886

Handling editor Seye Abimbola

Received 19 April 2018

Revised 13 June 2018

Accepted 16 June 2018
Check for updates

(c) Author(s) (or their employer(s)) 2018. Re-use permitted under CC BY-NC. No commercial re-use. See rights and permissions. Published by BMJ.

Department of Global Health and Population, Takemi Program in International Health, and FXB Center for Health and Human Rights, Harvard TH Chan School of Public Health, Boston, Massachusetts, USA

Correspondence to Dr Jesse B Bump; bump@hsph.harvard.edu

\section{ABSTRACT}

This paper addresses the need for conceptual and analytic clarity on nutrition governance, an essential underpinning of more effective approaches for undernutrition, the 'single greatest constraint to global development' and obesity, which already accounts for $4 \%$ of the world's disease burden and is growing rapidly.

The governance of nutrition, which is essential to designing and implementing policies to realise the right to food, is among the most important and most defining duties of society. But research and action on nutrition governance are hampered by the absence of conceptual rigour, even as the continuing very high burden of undernutrition and the rapid rise in obesity highlight the need for such structures. The breadth of nutrition itself suggests that governance is both needed and sure to be complicated.

This analysis explores the reasons attention has come to governance in development policy making, and why it has focused on nutrition governance in particular. It then assesses how the concept of nutrition governance has been used, finding that it has become increasingly prominent in scholarship on poor nutritional outcomes, but remains weakly specified and is invoked by different authors to mean different things. Undernutrition analysts have stressed coordination problems and structural issues related to the general functioning of government. Those studying obesity have emphasised international trade policies, regulatory issues and corporate behaviour. This paper argues that the lack of a clear, operational definition of governance is a serious obstacle to conceptualising and solving major problems in nutrition. To address this need, it develops a unified definition of nutrition governance consisting of three principles: accountability, participation and responsiveness. These are justified with reference to the social contract that defines modern nations and identifies citizens as the ultimate source of national power and legitimacy. A unified framework is then employed to explore solutions to nutrition governance problems.

\section{INTRODUCTION}

Nutrition is a requirement of all life and one of the most basic underpinnings of health, and as such is of great interest to all people. The right to food is therefore one of the most fundamental human entitlements and

\section{Key questions}

What is already known?

- The governance of nutrition is essential to addressing both undernutrition and obesity, but international and domestic actors have struggled in this area.

What are the new findings?

- Governance has risen on donor agendas since the fall of the Berlin Wall in 1989, and has become more important with the proliferation of international actors, increasing cross-border actions and greater globalisation of commerce and disease.

- Increased prominence of nutrition governance reflects greater donor engagement, the multisectoral nature of food, increasing obesity the need for health-related regulation of trade and food crises caused by climate change and food crop diversion.

- Existing governance frameworks do not clarify their principles; this paper develops a unified conceptualisation of nutrition governance from basic philosophy to show the relationships between undernutrition and obesity, clarify the challenges and illuminate opportunities for intervention.

\section{What do the new findings imply?}

- Nutrition governance and the right to food can be advanced by using the three elements of accountability, participation and responsiveness to assess all governance interventions and the performance of international actors.

a central responsibility for all states. ${ }^{12}$ The governance of nutrition, which is essential to designing and implementing policies to realise this right, ${ }^{34}$ is thus among the most important and most defining duties of society. Better governance, broadly defined, has potential to improve many aspects of nutrition, for instance by coordinating actions between sectors and agencies, promoting accountability of corporate actors, improving the food supply, increasing community ownership in intervention programmes, improving the responsiveness of government to citizen demand and helping to uphold the right to food. 
But both research and action on nutrition governance are hampered by the absence of clarity or consensus on the meaning of this concept, even as many problems highlight the need for such structures. Undernutrition alone has been called 'the single greatest constraint facing global development' ${ }^{5}$ and obesity accounts for nearly $4 \%$ of the entire global disease burden already and is increasing rapidly. ${ }^{6}$ Globalisation of the food industry has been linked to rising obesity, diet-related chronic disease and the nutritional transition. ${ }^{7}$ The breadth of nutrition itself suggests that governance is both needed and sure to be complicated. The production, distribution, sale and consumption of food engages agriculture, trade, transportation, education, health and other areas of both the public and private sectors.

Nonetheless, despite this need, basic questions about nutrition governance lack ready answers. For instance, what are the most important elements of governance? When planning a governance improvement intervention, where would one begin? For all the things that governance seems to be, what is it not? Is it the same as politics, or something different?

Conceptual rigour around nutrition governance would help navigate the seemingly impenetrable tangle of issues that now characterise this topic. The range of actors includes everything from individuals to the multinational food industry. The spectrum of influences is just as wide, including everything from personal preferences to national policies and global trade regimes, each of which has different sources of authority and legitimacy. In many scenarios, the lines of accountability are not obvious and even the relevant constituencies can be challenging to identify. Despite the profound influence of governance on nutrition, Sunguya et al have found that only $40 \%$ of low-income and middle-income country (LMIC) governments even have policies in this area. And although logic suggests that having a policy would be helpful, their analysis found no association with better nutrition outcomes. ${ }^{8}$ In many places, rapid urbanisation is exacerbating weak governance problems, ${ }^{9}$ and unregistered informal settlements expose the dysfunction of traditional welfare state approaches when citizens become invisible to the bureaucracy. ${ }^{10}{ }^{11}$ Where citizens do participate in the policy process, they may be ambivalent about issues experts view as urgent, ${ }^{12}$ or their opinions may be influenced by food industry marketing or sponsored research. ${ }^{13}{ }^{14}$ How would one analyse or manage these complex issues?

The purpose of this article is to rigorously analyse nutrition governance, which is essential to more effective intervention by national and international actors striving to uphold the right to food. First, I explain the literature review methods used to gather materials for analysis. Second, I examine why governance has become prominent on the health and development agendas. Third, I investigate the meaning of nutrition governance empirically, by assessing how the concept has been used. Fourth, I develop a clear definition of nutrition governance. Fifth, I present a framework for analysing nutrition governance and characterising its major features. In the conclusion, I use the framework to illuminate governance problems and corresponding opportunities for global-level actors.

\section{METHODS}

This inquiry began with a search of literature to gather information for the analysis and to gain insights into activities related to nutrition governance. To identify publications on nutrition governance, a keyword search for 'nutrition governance' was conducted in the PubMed database. ${ }^{\text {i }}$ PubMed was chosen as the starting point because it is the world's largest database of health and medical literature. To capture additional literature from the social sciences, humanities, newspapers and books, the JSTOR database was searched, as well. Searches with Google Scholar and a review of citations in the most directly relevant papers were used to complete the initial sample. ii

All results were reviewed and papers were retained if they used the term nutrition governance, or focused on nutrition and included aspects of governance as defined broadly by Lee $e t$ al to include accountability, transparency, participation, responsiveness, a consensus orientation, the rule of law, effectiveness and efficiency and equity and inclusiveness. ${ }^{15}$ Papers were excluded if they mentioned nutrition governance insubstantially or were irrelevant, for instance, as part of author affiliations, but not in the article itself. ${ }^{16-19}$ A more extensive discussion of methods is available as online supplementary annex 1 .

The final sample for analysis comprised 177 papers. Table 1 presents the search strategy for each database along with the number of papers obtained:

The limitations of this exercise include at least the following: these databases are biased towards English-language publications and western journals, and may not accurately capture governance work, even in these areas. Scholarship on governance may not have been indexed consistently or with the same keywords over the period of interest. The journals indexed by PubMed are not constant and the aggregate number has increased over this period. The searches used the keyword 'governance', which is a current term but may not have been the most commonly used term for describing its subject over the past 40 years. These limitations notwithstanding, the review is likely to have generated a reasonable sample of literature for analysing the aspects of nutrition governance of interest in this paper.

\footnotetext{
Search conducted 3 May 2015. Search detail: ('nutritional status' (MeSH Terms) OR ('nutritional' (All Fields) AND 'status'(All Fields)) OR 'nutritional status' (All Fields) OR 'nutrition' (All Fields) OR 'nutritional sciences' (MeSH Terms) OR ('nutritional' (All Fields) AND 'sciences' (All Fields)) OR 'nutritional sciences' (All Fields)) AND ('Governance (Oxf) ' (Journal) OR 'governance' (All Fields)).

ii These included: Mejía Acosta et $a l^{105}$; Gillespie et $a l^{97}$; Haddad et $a l^{106}$;. Sunguya et al. ${ }^{8}$
} 
Table 1 Nutrition governance literature search strategy and results by source

\begin{tabular}{|c|c|c|c|c|}
\hline Data source & Justification & Search criteria & Initial sample & Papers retained \\
\hline PubMed & $\begin{array}{l}\text { Largest database of } \\
\text { health and medical } \\
\text { literature }\end{array}$ & $\begin{array}{l}\text { Keywords: nutrition } \\
\text { governance }\end{array}$ & 98 & 89 \\
\hline JSTOR & $\begin{array}{l}\text { Broad coverage of } \\
\text { books, newspapers and } \\
\text { social science journals }\end{array}$ & $\begin{array}{l}\text { Nutrition in title or } \\
\text { abstract; governance in } \\
\text { full text }\end{array}$ & 83 & 59 \\
\hline Citation review & $\begin{array}{l}\text { Could detect relevant } \\
\text { papers not identified by } \\
\text { keyword searches }\end{array}$ & $\begin{array}{l}\text { Review of titles and } \\
\text { context of citation }\end{array}$ & $\begin{array}{l}\text { Four papers directly on } \\
\text { nutrition governance }\end{array}$ & 20 \\
\hline Google Scholar & $\begin{array}{l}\text { Broad coverage of } \\
\text { reports and other grey } \\
\text { literature }\end{array}$ & $\begin{array}{l}\text { Keywords: nutrition } \\
\text { governance }\end{array}$ & First 50 results & 9 \\
\hline Final sample for analysis & & & & 177 \\
\hline
\end{tabular}

\section{FINDINGS AND DISCUSSION}

Governance is such an obvious requirement for development that it is not intuitive why attention should have come to this area only in the past two or three decades, and especially in the last 10 years. I decided to investigate the reasons, hypothesising that they would help demonstrate the importance of nutrition governance and reveal the specific problems it is expected to solve.

\section{Governance and the development policy agenda}

Before the fall of the Berlin Wall in 1989, most aid was conditional on geopolitical alignment rather than on how states treated their own citizens. But after the Cold War, economic and political rights issues were no longer enmeshed in the larger US-Soviet ideological struggle. Freed from this constraint, western donors began to project their own political convictions via democratisation and governance projects. The growth of the rights movement and several international agreements on rights in the early 1990s testifies further to the power of this shift. $^{20}$

When the concern for state alignment evaporated, it helped bring attention to the role of governance in translating development aid into poverty reduction. This was an important factor in the introduction and subsequent popularity of the Sector Wide Approaches (SWAps) and other general budget support mechanisms that blossomed in the 1990s. ${ }^{21}$ After mixed results from the 1980s' Washington Consensus aid approach, it was also clear that the market alone would not solve all problems; the rise of governance was a partial retreat from that position, ${ }^{22}$ as was the embrace of public-private partnerships. ${ }^{23}$ Weaknesses in governance at various levels from the national to the global drew attention as constraints to health systems. ${ }^{24}$ The proliferation of actors in global health also spurred calls for better governance because of the need for coordination and accountability. ${ }^{25}$

Targeted aid and democratisation projects became even more closely linked after the 9/11 attacks brought emphasis in US policymaking to the problems of failed states and poor populations. After 9/11, US assistance was directed to poor people in failed states in hopes of preventing scarcity-induced radicalizsation. The emphasis on safety nets and social protection could be read as a move by donors to enhance democratic participation by the poor. ${ }^{26}$ However, these actions also fit neatly in the long legacy of aid programmes targeting health issues primarily because of their impact on trade and markets. $^{27}$

In the last 10 years, governance has become a well-established subfield in global health, in part because many problems related to governance have become more obvious. Governance was a natural follow-on focus after the decentralisation policies widely promoted in the 1990s, particularly because many of the formal policies and institutions designed to promote local engagement had not actually democratised decision making. ${ }^{28}$ But the growing attention to governance also reflects rapid globalisation. The rising threat of disease and the growth of interstate commerce both increase the need for shared decision making between diverse groups and entities. ${ }^{29}{ }^{30}$ Globalisation has also highlighted the need for governance over both health and trade, which since World War II have been institutionalised distinctly. ${ }^{31}$ Large-scale disease outbreaks, such as severe acute respiratory syndrome in 2003 and Ebola in West Africa in 2014 have made visible the importance of functioning governance mechanisms in health. ${ }^{32-34}$ Trade-related non-communicable diseases linked to tobacco, processed foods and other goods have exposed shortcomings in existing structures. $^{35}$

International actors have recognised governance in many of their projects and analyses. Beginning in 1996, the World Bank began collecting governance indicators every other year; since 2002, it has collected these data annually from 212 countries and territories. ${ }^{36}$ World Bank projects classified as 'Public Sector Governance' have become far more numerous over the years. In the 1980 s, there were 304 such projects. In the 1990s, there 
were 849 projects, almost three times as many. In the 2000s, there were 1301, a more than fourfold increase from the 1990s. ${ }^{\text {iii }}$ The UK's Department for International Development began focusing on governance in the early 2000s, introduced a governance assessment measure in $2006^{22}$ and spent annually over half a billion pounds on governance projects 2004-2009, as disclosed in a review of those years. ${ }^{37}$ In 2007, WHO focused its flagship World Health Report on global health security, which emphasised governance. ${ }^{38}$

\section{Rising attention to nutrition governance}

Against this background of interest in governance within development, five major trends have intensified the focus on nutrition governance. First, there have been many coordination problems. These came to the fore with the embrace of rights issues by donor countries, which allowed UN entities and other actors to uphold the right to food by intervening across national boundaries. This happened under UN mandate for the first time in 1989 in Sudan and quickly became commonplace. UN entities, bilateral donors and non-governmental organisations (NGOs) all began operating across borders, meaning that coordination challenges grew with the proliferation of both actors and complex emergencies. ${ }^{20}$ The multiplication of new NGOs, UN entities, corporations and others engaged in nutrition has continued and represents a growing challenge for coordination. ${ }^{25}{ }^{39}$ Additionally, the complexity of nutrition and its engagement with a great many sectors-agriculture, education, trade, health and others-present many coordination challenges.

Second, food and nutrition interventions could be targeted at the community level and could give voice to poor citizens by promoting their participation. Hence, they were seen as natural vehicles to advance donors' general priorities in economic and political rights, and in attempting to prevent scarcity-induced radicalisation in failed states. More broadly, donors attempted to enhance democratic participation by the poor, but questions of how donor-driven governance models were supposed to interact with existing governance structures largely went unaddressed. ${ }^{26}$

Third, the advance of globalisation highlighted the need for supranational regulation and strengthened governance at all levels. In 1999, Lang argued that globalisation was undermining traditional governance of food because national authority was not capable to regulating multinational businesses or countering their marketing. ${ }^{40}$ The global growth of fast food and advertising largely bypassed health authorities because it was regulated internationally only as a trade issue with little reference to health consequences. ${ }^{41}$ Others have advanced similar points on the importance of 'food governance', ${ }^{42}$ the need for international legal standards

\footnotetext{
iii Data obtained 18 March 2016 from World Bank's 'Projects and Operations' website: http://www.worldbank.org/projects/ search?lang=en\&search Term $=\&$ mjthemecode_exact $=2$
}

for food and nutrition, perhaps similar to the Framework Convention on Tobacco Control, and coordinated action by the World Bank, WHO and the UN. ${ }^{35} 4344$

Fourth, real food prices rose quickly in the 2000s, peaking in 2008 and 2011, driven by depreciation in the dollar, diversion of some crops to biofuel use, oil price appreciation, export restrictions, demand surges, droughts and other factors. ${ }^{456}$ Between 2000 and 2011, food prices increased $183 \%$ in real terms. ${ }^{47}$ The disastrous humanitarian consequences of this increase, including conflict and instability, ${ }^{48}$ generated political motivation for discussing food security, agriculture and trade policy and other aspects of global nutrition, particularly with respect to undernutrition. ${ }^{4-51}$

Fifth, multilateral organisations and academics have been active. Governance was identified as one of the principal weaknesses in global nutrition by WHO's Commission on Social Determinants of Health in $2008^{52}$; a Lancet commission cited governance problems as a central obstacle to effective international intervention against undernutrition. ${ }^{53}$ Also in 2008 (formalised 2011), the Food and Agriculture Organization, Unicef and World Food Programme (WFP) agreed to launch Renewed Efforts Against Child Hunger and undernutrition (REACH) to strengthen UN actions to fight hunger and malnutrition by coordinating actions within recipient countries. In 2009-2010, WHO and many partners launched the Scaling Up Nutrition (SUN) movement to spur progress against undernutrition. ${ }^{54}$ In 2010, WHO's Nutrition Landscape Information System launched with a series of governance indicators, ${ }^{55}$ which has made it easier to quantify and demonstrate the large impact of governance on nutrition. ${ }^{8}$ Since 2011, REACH has focused on strengthening nutrition management and governance, and supporting multisectoral nutrition actions, such as nutrition-sensitive programming. ${ }^{39} 56$ These multilateral efforts have all brought attention to governance, although some have attracted criticism for expanding the influence of the private sector in public health policy. ${ }^{5758}$

This historical analysis reveals why nutrition governance is so crucial. First, it is essential to realise the right to food. Second, it is a tractable place to advance development through encouraging participation and democratisation, and as such is a powerful lever to realise many rights. Third, it is needed to coordinate between the many sectors important to nutrition, and among the many agencies and entities operating domestically and internationally. Fourth, it is required to address the affects of trade on health, particularly in the globalised food industry.

\section{The need for governance}

A review of the literature identified in this search finds that most authors use 'governance' in explanation of their primary findings, but usually do not focus on governance itself. In this usage, one theme could be called 'the need for governance', which investigates problems and 
explains them with reference to weak or missing governance. At the global level, this literature includes calls for better governance as global and national policy environments become more complex ${ }^{59}$ and the globalisation of the food industry overwhelms existing governance structures. ${ }^{60}$ Governance problems are central to the maldistribution underlying local or regional food insecurity even though global production is adequate. ${ }^{61}$ Quality of governance was identified as an important determinant of progress towards the Millennium Development Goals and successful primary healthcare implementation, ${ }^{62}$ and as a fundamental component of high performing states: '...the most effective, relevant national policies will emerge from a system of governance that firmly connects the needs of the poor to a politically responsive local government that has the technical and institutional capacity to act'. ${ }^{3}$ A high-profile Lancet article focusing mainly on the global level identified accountability and participation as leading problems: 'The international community needs to identify and establish a new global governance structure that can provide greater accountability and participation for civil society and the private sector'. ${ }^{53}$ The WHO Code of Marketing of Breast Milk Substitutes has provisions for punishing violators, but governance problems have rendered the code largely unenforced and ineffective. ${ }^{63-65}$ Donors have attempted to promote accountability and participation mechanisms, but many interventions do not translate into benefits for those not already enfranchised, such as women, ${ }^{66}$ and many efforts have been assailed by activists for advancing private sector influence in public health processes. ${ }^{586768}$

The importance of nutrition governance is demonstrated by experiences and analyses in many national and local contexts, as well. Some of the largest are collective action problems. ${ }^{69}$ In India, which has among the highest burdens related to suboptimal nutrition, governance problems have been deemed more significant than scientific or technical obstacles,${ }^{70}$ and is needed to translate economic growth into progress against undernutrition. ${ }^{71}$ Looking at urban areas of the same country, Bhojani et al characterised the main governance problems as weak regulation of quality in the private sector; poor coordination across care providers in the public and private sectors and between clinics, health centres and hospitals; rampant bribery and the absence of systems to respond to formal grievances or provide accountability to citizens. $^{72}$ In a policy analysis of maternal and child health in Pakistan, Siddiqi et al argued that good governance is needed to translate policies into results. ${ }^{73}$ In a discussion of food security and fisheries, weaknesses in governance were revealed in overfishing, depletion of stocks, minimal enforcement, low oversight and inadequate coordination of policies and actions between national and global authorities. ${ }^{74}$ Understanding governance structures is also extremely important for designing strategies to advance food policy on political agendas. ${ }^{75}$ The politics of food policy hinges both on government leadership and activism by civil society organisations. ${ }^{76}$
Others used 'governance' as an organising category to identify coordination problems, which arise from nutrition's intersectoral nature, as reported in India and Brazil, to name two examples. ${ }^{77} 78$ Coordination problems can arise at the intersection of public and private sectors-the Bangladesh Government attempted to advance governance in its policies, but the exercise's impact was attributed to NGO partners. ${ }^{79}$

Some analysts have assessed the effect of governance through comparative and synthetic investigations. In a comparison of fragile states, those with higher quality of governance were more likely to join SUN, while the 'prevalence of malnutrition, health system functioning and level of citizen empowerment had little or no impact' on the decision to join. ${ }^{80}$ A synthetic review of 58 controlled evaluations argued that 'nutrition is now recognised to be a governance issue', and that better governance was associated with lower prevalence of child undernutrition. ${ }^{81}$ A comparison of water quality in Brazil, Ecuador and Malawi found '...that access to safe water could be improved if certain water governance challenges were addressed: coordination and data sharing between ministries...; monitoring and enforcement of water quality laws; and sufficient technical capacity to improve administrative and technical management of water services..."

'Governance' has also been used as a general category for describing specific interventions, many of them successful. Extensive community engagement helped address governance problems in Vietnam. ${ }^{83}$ Collaboration and coordination problems were resolved with shared governance structures in Colombia. ${ }^{84}$ In both Australia and the UK, the clarity and transparency of governance arrangements was important to facilitating cooperation and coordination in obesity reduction efforts. ${ }^{85}$ In the Philippines, long-term capacity building in both the public and private sectors has facilitated governance by collecting and analysing data to generate evidence for improving policymaking. ${ }^{87}$ Systematic data analysis in Haiti has helped to elucidate many factors that promoted good nutrition governance, including 'effective evidence-based advocacy, partnerships and design, implementation and scale-up of nutrition-specific and sensitive interventions'. ${ }^{\prime 8}$

Another area of scholarship using governance has focused on citizen attitudes and perceptions to explore why technically sound policies are challenging to adopt and implement. Reasons include popular ambivalence towards experts' opinion, ${ }^{12}$ or the shaping of debate by food industry marketing or sponsored research. ${ }^{13} 14$ Contested views of the role of the state versus the private sector were central to the growing obesity epidemic in Australia, where many people did not want the state to counter fast food advertising. ${ }^{89}$ Also, politicians were the least trusted group for information on food, according to a telephone survey by the same researchers (farmers were the most trusted).$^{90}$ This contest for influence is very difficult for public health advocates. Denmark introduced a saturated fat tax in 2011, supported with 
public health arguments, but it was opposed by the food industry and related actors. Although the tax began to change the national diet as public health advocates had hoped, the tax had no organised supporters and the food industry successfully lobbied for its abolishment the following year. ${ }^{91}$

Calls for improved governance were not always matched by clarity about exactly what is needed, suggesting that governance can be challenging to specify and is not always discussed in meaningful detail. Given the complexity and vagueness of both 'nutrition' and 'governance', this finding is hardly surprising. Others have reached this same conclusion. A systematic review of health system barriers to antiretroviral therapy provision found that many authors cited governance problems, but the collective evidence was weak because individual cases included too little context to convey what this meant in detail. ${ }^{92} \mathrm{In}$ a systematic review of the impact of health systems and policies on behaviour change to promote child survival in LMICs, Velez et al concluded, 'The evidence directly addressing how to improve the financing and governance of health systems was weak or not available'. ${ }^{93}$ Another broad review focused on agriculture research, finding that despite vast influence of governance on the agriculture-nutrition impact, only six studies, just $4 \%$ of the sample, actually focused on governance. ${ }^{94}$

\section{Addressing nutrition governance directly}

A far smaller portion of the literature reviewed in this study focused directly on nutrition governance, typically regarding undernutrition. In historical perspective, undernutrition, hunger and food insecurity are all wellknown problems that surely predate the written record, whereas obesity has become a public health concern only very recently. In this light, it may not be surprising that a majority of the papers on nutrition governance concerned undernutrition and concentrated on the governance issues related to that problem. The major institutional actors mentioned in the literature review focus the preponderance of activities on undernutrition, including Unicef, SCN, WFP and WHO, and major initiatives such as SUN and REACH, although both Unicef and WHO have smaller portfolios targeting obesity.

Some authors defined nutrition governance using broad definitions. As illustrated by Solon's articulation, 'governance' may be simply stated: 'Governance is the process of decision-making and implementation'. ${ }^{87}$ Pinstrup-Andersen and Watson take a similarly broad approach in writing that 'governance deals with how... conflicting interests are resolved', and may be defined as '...the exercise of authority or management of resources through institutions, policies, traditions, cultures and societal norms'. ${ }^{95}$ In these and similar cases, the inclusiveness makes it difficult to understand what would be excluded from 'governance', and it is hard to imagine what specific interventions would follow naturally from the definitions.
Other authors invoked governance to discuss or analyse a limited subset of concepts. For instance, the highly influential Lancet paper by Morris et al focused on governance barriers to international action against undernutrition that could be categorised as coordination, accountability and distributional. ${ }^{53}$ These categories are intuitive because they are at the root of food insecurity, and have long been important in undernutrition scholarship and programming. Coordination problems are common because undernutrition often relates to complicated circumstances in which many actors operate without clear lines of authority, responsibility or accountability. Conflict, natural disaster and multiple failures of markets and/or states are all common settings for undernutrition. The UN System Standing Committee on Nutrition (SCN) was founded in 1977 (as SubCommittee on Nutrition) with the express purpose of coordinating UN actions against nutrition problems. ${ }^{96} \mathrm{~A}$ major stated reason for launching SUN in 2010 was to harmonise views, policies and actions across a broader set of stakeholders including countries and donors. ${ }^{97} 98$ The proliferation of global health actors has exacerbated this problem further. ${ }^{99}$

Accountability problems are commonly referenced because many analysts view governments as guarantors of food security, and insecurity thus represents a government failure, which might be rectified or reduced if governments were more accountable to their citizens. The intersectoral nature of food security also means that many parts of a government may be responsible, but hard to hold accountable. ${ }^{70} 100$ Increasing the participation and voice of at-risk groups is a common recommendation. ${ }^{81}$ One important pathway is that greater participation and better governance are associated with improved access to safe water, although there are likely many more, as well. ${ }^{100} 101$

Adequacy of global food production and its persistent scarcity in particular settings points to distribution, or allocation issues. ${ }^{100}$ The same dynamic plays out within countries, where poor distribution systems leave some areas vulnerable even as food is sufficient when measured at the national level. ${ }^{102}$ Distributional issues are not strictly limited to food-the distribution of rights and entitlements are also core governance issues with large implications for nutrition. ${ }^{73} 103104$

Among the most prominent nutrition governance frameworks identified in this review was developed at the Institute for Development Studies by Mejía Acosta and Fanzo, and Haddad et al. ${ }^{105} 106$ The framework highlights cooperation and coordination-both prominent themes in undernutrition as explained above-and also adds sustainable funding and monitoring and advocacy. The explicit inclusion of funding recognises the central requirement of adequate resources, which the authors characterise as the 'cement' that holds cooperation and coordination together. ${ }^{105}$ The monitoring and advocacy category acknowledges the need for governments to collect relevant information and produce analyses to 
understand where there are problems, design and implement solutions and track progress. Advocacy represents the critical role of civil society in detecting problems, raising awareness and facilitating solutions, whether by direct delivery or influencing the government.

Very different views on governance came from studies focusing on obesity, where primary themes include the globalisation of food, the products and marketing of multinational corporations (MNCs) and individual lifestyle choices. ${ }^{40-42}{ }^{63}{ }^{107}$ Globalisation has changed the landscape of food and nutrition by concentrating power in large firms, changing consumer taste through marketing, and limiting the effectiveness of traditional governance mechanisms. Representation, participation, voice, accountability and regulation all are rooted in national structures and are easy to circumvent for MNCs. Where accountability is discussed, it emphasises corporate accountability ${ }^{108}$ and tends to focus on global level regulatory issues concerning trade and health. ${ }^{42}$

Addressing the Australian context, Sacks et al developed a matrix of sectors and governance levels for thinking about some of these issues, which they used to identify policy options. ${ }^{109}$ The sectors ranged from primary production and food processing to distributions, marketing, retail and catering/food service. Governance levels include local, state, national and international. Although the authors do not use the term, this can be considered a nutrition governance framework. Sacks et al identify policy issues and the level of government where they may be addressed. For example, in food processing, safety standards are usually a state government responsibility and product composition standards are usually decided at the national level.

\section{Analysing nutrition governance frameworks}

These nutrition governance frameworks include elements that are well supported by intuition and research, and draw attention to some critical areas of nutrition governance in both undernutrition and obesity. Their many strengths are evident in the above review: individually, they identify some of the most pressing issues in nutrition governance, and collectively, they provide a place to begin understanding the very difficult landscape of one of humanity's greatest problems.

However, a synthetic view of scholarship on nutrition governance finds an incomplete picture. There is no shared language or methods common to all the frameworks, and none articulate the philosophical principles on which they are based. Furthermore, they emphasise global-level, technical perspectives, and tend not to consider political issues or variation in state capacity, which can run from strong to absent, as in humanitarian settings. This is limiting, and sometimes becomes problematic. A main limitation is that the frameworks explain only the part of nutrition governance on which they are focused, but do not illuminate the larger landscape. Additionally, the lack of a philosophical basis means that they have difficulty explaining their priorities or defending their boundaries, should the need arise. For instance, the frameworks by Morris et al and Mejía Acosta and Fanzo do not include participation or transparency among their central elements. This choice may reflect that the dominant historical problem in undernutrition is inadequate food, and in this perspective the most basic citizen view can be presumed-the demand for more food. It may also reflect a strong focus on the multilateral architecture of aid, which tends to neglect crucial factors such as domestic political commitment. A full-text search of the Sacks et al framework article does not find a single mention of either 'cooperation' or 'coordination'. It is unlikely that any analyst of governance-including the authors of these fine papers-would say that participation is unimportant, or that transparency is seldom needed, or that coordination is trivial.

Observing the different elements in nutrition governance frameworks raises a dilemma that can be resolved by weighing breadth and depth in either of two directions. In the more inclusive direction, additional elements are added to the framework to increase its explanatory coverage, as with some of the other frameworks covered earlier. In the direction of specificity, the framework must be qualified to particular settings in which the included elements did matter or might matter most. Neither direction is completely satisfying because they trade off universality and specificity without establishing the relationship between the two.

An obvious division in uses of nutrition governance lies between those concerned with undernutrition and those focused on obesity. The papers reviewed here focused on one or the other, but not both. This division appears to be highly influential on the governance problems that were reported. The authors focusing on undernutrition typically highlighted administrative issues, such as coordination for service delivery, distributional problems and responsiveness or accountability to citizen demand. The authors focusing on obesity typically emphasised political or political economic issues, including the globalisation of the food industry, multinational corporate accountability problems, coordination for regulatory and policy making purposes and the political economy of production and consumption, which includes the contest for public opinion and allows for conflict over food choices. This division suggests that either analysts employ different definitions of governance or refer to 'governance' with reference to specific manifestations rather than underlying principles.

The absence of discussion on these underlying principles creates additional problems, as well. First, these definitions do not prioritise the importance of their elements, meaning it is difficult to know if anything is more important than anything else. Second, the lack of prioritisation disguises the interaction or possible causality between the elements. Third, it is hard to determine what would not qualify as a governance problem, which disguises the difference between issues best approached from this perspective and those that could be addressed 
more easily with another lens. These limitations pose challenges for conceptualising nutrition governance more broadly or attempting to implement solutions.

Although it is not the focus of this paper, I speculate that historical differences between the communities studying undernutrition and obesity account for some of the differences in perspective. The authors writing on undernutrition were more likely to have technical backgrounds in medicine, nutrition sciences, agriculture and related areas. Those focusing on obesity were more likely to have experience with law and the social sciences, and many had previous experience with tobacco control or other areas of globalised trade and health, and tended to draw on scholarship by leading authors in those areas. ${ }^{15} 3031110111$ There was little or no overlap in these groups.

\section{A unified framework for nutrition governance}

As the basis for equitably realising the right to food and upholding the right to health, nutrition governance is grounded in universal principles. But as I have discussed above, current articulations of nutrition governance are divided by problem type-undernutrition or obesityand grounded in specific contexts where those problems are found. At one time, undernutrition was the only nutrition problem, and when obesity first emerged as a public health problem it was confined to relatively distinct geographies. This is no longer the case. The nutrition transition $^{112}$ and the double burden of undernutrition and obesity mean that single countries are required to deal with both problems. Accordingly, it is for both philosophical and practical considerations that a unified framework for nutrition governance is desirable.

The starting point for a unified nutrition governance framework is a definition of governance itself. A simple and classic definition of politics was offered by Lasswell in the 1930s as who gets what, when and how, which refers to the underlying definition of politics as a distributive process. ${ }^{113}$ I argue that governance can be considered as the structures through which such distributive decisions are made and enforced. This conceptualisation emphasises the structural or formalised elements of the process, which is reflected in common usage of 'governance' in connection with a normative judgement, as in good or strong governance, or bad or weak governance. The conception of something that can be judged this way means there is a standard for doing so, which in this case I define as any of the three dimensions of governance I will propose.

The basis for my conceptualisation of governance is the social contract that underlies modern nations, as first articulated by Rousseau ${ }^{114}$ and Locke ${ }^{115}$ in the Enlightenment. This idea holds that citizens cede some powers to the state in exchange for the protection of their remaining rights, and is based on the principle that citizens are the ultimate source of power and the ultimate conveyors of legitimacy. ${ }^{114} 115$
I apply the concept of citizens as the source of power and authority to governance and propose that it can be distilled around the primary principles of accountability, participation and responsiveness. Accountability recognises citizens as the source of state power. Participation comes from the recognition that state legitimacy is conditioned on the consent of those governed. Responsiveness refers to the timeliness of the link between what people want, as expressed by participation, and the accountability that may be exercised when needed services are not forthcoming. With particular reference to nutrition, timeliness can be of vital importance, and thus responsiveness is elevated to primary status along with accountability and participation, even though it could be argued that these latter two principles should already reflect responsiveness. Evaluating governance means that each principle should be measured with reference to the authority and legitimacy granted by citizens and their judgements of performance. Stated concisely:

Nutrition governance is the ability of institutions and other structures to uphold the principles of participation, responsiveness, and accountability in the realization of the right to food and the achievement of optimal nutrition for all citizens.

These three primary principles are central to human rights law, appearing prominently in the International Covenant on Economic, Social and Cultural Rights, ${ }^{116}$ and beneath them lie many others. As reviewed by Lee et al., for the WHO Commission on Social Determinants of Health, broad conceptions of governance include the three mentioned above and also transparency, a consensus orientation, the rule of law, effectiveness and efficiency and equity and inclusiveness. ${ }^{15}$ No doubt there are many more, to be sure. However, I argue that these others are secondary. For instance, I would argue that accountability, participation and responsiveness all require transparency, which for that reason is not a leading independent category. Similarly, I argue that the leading three also depend on equity and the rule of law. A consensus orientation, effectiveness and efficiency and equity and inclusiveness are all factors that citizens would reflect in their participation and their preferences for accountability.

With this definition established, it can be used to clarify governance challenges and how they relate to each other. In my view, existing scholarship can be categorised in four areas, as shown below in table 2 as a map of sample nutrition governance problems in undernutrition and obesity at the national and global levels. This exercise reveals how existing frameworks tend to focus on only one square, for example, undernutrition at the global level, as by Morris et al. ${ }^{53}$ table 3 further develops this idea by applying the three main pillars of accountability, participation and responsiveness to undernutrition and obesity. Note that this is a characterisation of existing scholarship, and is not inclusive of many important issues that are covered lightly or not at all. Inadequate attention 
Table 2 Sample nutrition governance problems at national and global levels

\begin{tabular}{|c|c|c|}
\hline & Undernutrition & Obesity \\
\hline Global & $\begin{array}{l}\text { Accountability } \\
\text { and } \\
\text { coordination of } \\
\text { actors } \\
\text { Diversion of } \\
\text { food crops to } \\
\text { other uses } \\
\text { Distribution } \\
\text { problems } \\
\text { Focus of Morris } \\
\text { et al (2008) }\end{array}$ & $\begin{array}{l}\text { Effects of globalised } \\
\text { trade on health } \\
\text { Supranational } \\
\text { regulation of } \\
\text { food, agriculture } \\
\text { companies }\end{array}$ \\
\hline National & $\begin{array}{l}\text { Coordination } \\
\text { of government } \\
\text { sectors, public- } \\
\text { private actors } \\
\text { Safety net and } \\
\text { distributional } \\
\text { issues } \\
\text { Focus of Mejía } \\
\text { Acosta and } \\
\text { Fanzo (2012) }\end{array}$ & $\begin{array}{l}\text { Contested } \\
\text { perceptions of } \\
\text { unhealthy foods } \\
\text { Food environment } \\
\text { Dietary guidelines, } \\
\text { advice } \\
\text { Focus of Sacks et al } \\
\text { (2008) }\end{array}$ \\
\hline
\end{tabular}

has been paid to the interaction of global, national and local levels, or to the differences in capacity and context in strong states, weak stakes, humanitarian disasters or elsewhere, for instance.

Employing the three categories of accountability, participation and responsiveness facilitates a comparison of undernutrition and obesity problems from a governance perspective. This exercise highlights undernutrition as a problem of dysfunctional structures-mainly people do not get what they want and cannot enforce accountability, although there can be information and education aspects, as well. Aligning services with wants thus addresses the problem, meaning that people who need food then get food. Obesity problems are different-people get too much of what they want, or want unhealthful things (these are also causes of undernutrition-overweight). Because of this, obesity can - and does-occur where governance structures function well. In such cases, a principal challenge lies in the contest for perception and opinion on food and related policies. The formal structural governance problems are subtle because they concern broad political economy issues that are hard to analyse and remain unknown to many people. These include tax policy, agricultural policies, inadequate government authority and regulatory capture and ineffectiveness. Although the beneficiaries of the food industry are engaged, those harmed are not necessarily inclined to think of themselves as harmed or to identify any particular agent as the cause of their problems.

\section{CONCLUSION}

Governance has emerged as an important focus in development programming over the last three decades, and nutrition governance in particular has great potential to improve health. But this analysis finds that although the concept of 'nutrition governance' has become increasingly prominent in scholarship on poor nutritional outcomes, it remains weakly specified and is invoked by different authors to mean different things. An important division of approaches and general meanings exists between those who have focused on undernutrition and those who have concentrated on obesity. Those in the former group have stressed coordination problems and structural issues related to the general functioning of government and the low accountability of international actors. Those in the later group have emphasised international trade policies, regulatory issues and corporate behaviour.

By developing a definition of governance based on the social contract and applying it to nutrition, this paper presents a framework for considering all nutrition problems at the same time. Using the framework to assess undernutrition and obesity finds that its principles apply well in either case, but they indicate different weaknesses. In general, undernutrition problems relate to structural flaws, such as poor or absent accountability, weak or missing participation or inadequate responsiveness. Under the assumption that people do not want to be undernourished, then the problem can be crudely characterised as unmet demand-citizens are not getting a service entitlement they need and want. Some of these issues may also underlie obesity problems, but those scenarios are additionally characterised by more insidious dynamics. Accountability and participation can be strong, but may be corrupted by marketing and other influences on citizen perception. The demands expressed by citizens may be accurately—and harmfully—expressed in unhealthy foods, habits and environments. This shifts the intervention area from governance structures per se to the inputs-the things that citizens want-and can be characterised as a contest for perceptions about good choices in food, food policy and related issues of regulation, tax and trade.

The vast prevalence of obesity and undernutrition shows that governments, international agencies and other actors have failed to uphold the right to food and optimal nutrition for most of the world's citizens. This is among the leading embarrassments to all humanity, and is of such widespread consequence that delay in remedial action cannot be justified. The clarification of the three basic governance principles of accountability, participation and responsiveness provides categories for assessing government performance and aid programmes alike. Advancing the state-citizen contract is central to all areas of development, and hence the imperative to assess how aid affects governance applies to every donor-supported project. Projects that bypass or weaken the social contract have been common in the past, but should never be accepted. These ideas may be particularly useful to civil society groups and academic organisations that monitor development assistance efforts and seek to compel governments to uphold the right to food. 
Table 3 Comparison of governance areas for undernutrition and obesity at global and national levels

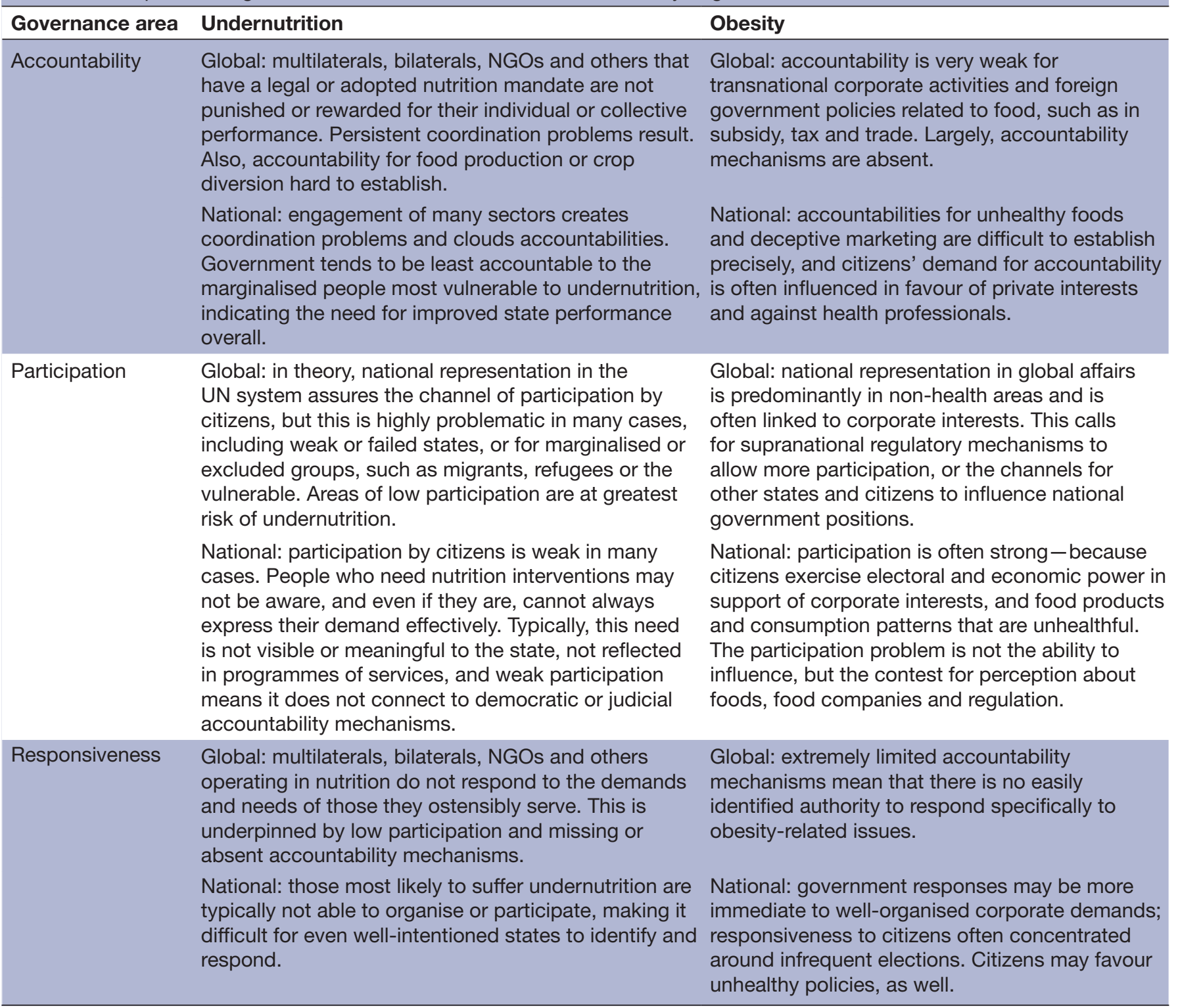

For global level institutions, the implications of this analysis lie in two areas. For undernutrition problems, interventions to strengthen the connection between states and their citizens and mechanisms to allow states to hold international actors accountable would help address many major weaknesses. In turn, this would help states and international actors better promote participation and become more responsive. This task is urgent. Undernutrition tends to affect the most vulnerable and is prioritised in the Sustainable Development Goals for that reason. With particular reference to obesity, many of the governance problems identified by this paper have international dimensions that constrain national policy solutions. Globalisation is increasing the importance of this dynamic and points to an urgent need for supranational regulation of the food industry and concerted efforts to contest the perceptions it advances through marketing. No country has yet succeeded in turning the still-rising tide of obesity, regardless of the strength of its governance or the size of its income, further indicating the need for coordinated global action.

Twitter@jessebump

Acknowledgements I gratefully acknowledge helpful comments from Prerna Banati, Yarlini Balarajan, Carmen Jacqueline Ho, and the anonymous reviewers. All errors remain my own.

Contributors I am the sole author of this work and am responsible for its content. Funding UNICEF Office of Research—Innocenti.

Competing interests None declared.

Patient consent Not required.

Provenance and peer review Not commissioned; externally peer reviewed.

Data sharing statement No additional data are available.

Open access This is an open access article distributed in accordance with the Creative Commons Attribution Non Commercial (CC BY-NC 4.0) license, which permits others to distribute, remix, adapt, build upon this work non-commercially, and license their derivative works on different terms, provided the original work is 
properly cited, appropriate credit is given, any changes made indicated, and the use is non-commercial. See: http://creativecommons.org/licenses/by-nc/4.0/.

\section{REFERENCES}

1. De Schutter O. UN Special Rapporteur on the right to food. Report on agroecology and the right to food, 2014.

2. UN CESCR. General Comment No. 12: The right to adequate food, UN Doc. E/C, 1999.

3. Villarreal M, Stloukal L. Population, development and food security: an unresolved challenge for the twenty-first century. Genus 2005;61:215-46.

4. Narula S. The right to food: Holding global actors accountable under international law. Colum J Transnat'/ L 2005;44:691.

5. Engesveen K, Nishida C, Prudhon C, et al. Assessing countries' commitment to accelerate nutrition action demonstrated in PRSPs, UNDAFs and through nutrition governance. SCN news / United Nations, Administrative Committee on Coordination, Subcommittee on Nutrition 2009;37:10-16.

6. Ng M, Fleming T, Robinson M, et al. Global, regional, and national prevalence of overweight and obesity in children and adults during 1980-2013: a systematic analysis for the Global Burden of Disease Study 2013. The Lancet 2014;384:766-81.

7. Hawkes C. Uneven dietary development: linking the policies and processes of globalization with the nutrition transition, obesity and diet-related chronic diseases. Global Health 2006;2:4

8. Sunguya BF, Ong KIC, Dhakal S, et al. Strong nutrition governance is a key to addressing nutrition transition in low and middle-income countries: review of countries' nutrition policies. Nutr J 2014;13:65.

9. Crisp J, Morris T, Refstie H. Displacement in urban areas: new challenges, new partnerships. Disasters 2012;36:S23-42.

10. Subbaraman R, O'brien J, Shitole T, et al. Off the map: the health and social implications of being a non-notified slum in India. Environ Urban 2012;24:643-63.

11. Poverty WJ. Invisibility and the Welfare State in the Developing World. Hasmath R, ed. Inclusive Growth, Development and Welfare Policy: A Critical Assessment. New York: Routledge, 2015:211-28.

12. Oliver JE, Lee T. Public opinion and the politics of obesity in America. J Health Polit Policy Law 2005;30:923-54.

13. Brownell KD, Warner KE. The Perils of Ignoring History: Big Tobacco Played Dirty and Millions Died. How Similar Is Big Food? Milbank Quarterly 2009;87:259-94.

14. O'Connor A. Coca-Cola Funds Scientists Who Shift Blame for Obesity Away From Bad Diets. New York Times 2015.

15. Lee K, Koivusalo M, Ollila E, et al. Globalization, Global Governance and the Social Determinants of Health: A review of the linkages and agenda for action. Ottowa: Globalization and Health Knowledge Network, 2007

16. Aberman NL, Rawat R, Drimie $\mathrm{S}$, et al. Food security and nutrition interventions in response to the AIDS epidemic: assessing global action and evidence. AIDS Behav 2014;18 Suppl 5(S5):554-65.

17. Steyn NP, Mchiza Z, Hill J, et al. Nutritional contribution of street foods to the diet of people in developing countries: a systematic review. Public Health Nutr 2014;17:1363-74.

18. Tirivayi N, Groot W. Health and welfare effects of integrating AIDS treatment with food assistance in resource constrained settings: A systematic review of theory and evidence. Soc Sci Med 2011;73:685-92.

19. Tirivayi N, Koethe JR, Groot W. Clinic-Based Food Assistance is Associated with Increased Medication Adherence among HIVInfected Adults on Long-Term Antiretroviral Therapy in Zambia. $J$ AIDS Clin Res 2012;03:171.

20. Marchione TJ. The right to food in the post-Cold War era. Food Policy 1996;21:83-102.

21. Hill PS. Bilateral health aid: lessons from Europe. Aust N Z J Public Health 2000;24:432-6.

22. Hout W. Development and governance: an uneasy relationship. In: Hout W, Robison R, eds. Governance and the Depoliticisation of Development. London: Routledge, 2009:29-43.

23. Chopra M. Public-Private Partnerships for Combating Micronutrient Malnutrition. Food Nutr Bull 2001;22:431-5.

24. Reich M, Takemi K. Governing Health Systems, 2013.

25. Evans TG. Governance for global and national health: a role for framework conventions? Health Hum Rights 2013;15:E5-7.

26. Marchione TJ. Interactions with the recipient community in targeted food and nutrition programs. J Nutr 2005;135:886-9.

27. Address $O$. Proceedings of the fourth international congress on tropical medicine and malaria. Washington, D. C.: Government Printing Office, 1948.
28. Cornwall A, Coelho VS. Spaces for change?: the politics of citizen participation in new democratic arenas: Zed Books, 2007.

29. Gostin LO, Mok EA. Grand challenges in global health governance. Br Med Bull 2009;90:7-18.

30. Lee K. The Pit and the Pendulum: Can globalization take health governance forward? Development 2004;47:11-17.

31. Lee K, Sridhar D, Patel M. Bridging the divide: global governance of trade and health. Lancet 2009;373:416-22.

32. Fidler DP, Gostin LO. The new International Health Regulations: an historic development for international law and public health. $J$ Law Med Ethics 2006;34:85-94.

33. Roemer-Mahler A, Elbe S. The race for Ebola drugs: pharmaceuticals, security and global health governance. Third World Q 2016;37:487-506.

34. Gostin LO, Friedman E. Ebola: a crisis in global health leadership, 2014.

35. Magnusson RS. Non-communicable diseases and global health governance: enhancing global processes to improve health development. Global Health 2007;3:2.

36. Kaufmann D, Kraay A, Mastruzzi M. Governance matters VIII: aggregate and individual governance indicators, 1996-2008, 2009. World bank policy research working paper.

37. DFID. Governance Portfolio Review Summary: Summary Review of DFID's Governance Portfolio 2004-2009 London: DFID. 2011 https://www.gov.uk/government/uploads/system/uploads/ attachment_data/file/67458/governance-portfolio.pdf.

38. WHO. The world health report 2007: A safer future: global public health security in the 21st century. Geneva: World Health Organization 2007 http://www.who.int/whr/2007/en/.

39. REACH. Joint Evaluation of the REACH Initiative (Renewed Effort Against Child Hunger and Undernutrition) 2011-2015, 2015.

40. Lang T. Diet, health and globalization: five key questions. Proc Nutr Soc 1999;58:335-43.

41. Chopra M, Galbraith S, Darnton-Hill I. A global response to a global problem: the epidemic of overnutrition. Bull World Health Organ 2002;80:952-8.

42. Rayner G, Hawkes C, Lang T, et al. Trade liberalization and the diet transition: a public health response. Health Promot Int 2006;21(suppl_1):67-74.

43. Magnusson RS. Rethinking global health challenges: towards a 'global compact' for reducing the burden of chronic disease. Public Health 2009;123:265-74.

44. Yach $\mathrm{D}$. The role of business in addressing the long-term implications of the current food crisis. Global Health 2008;4:12.

45. Headey D, Fan S. Anatomy of a crisis: the causes and consequences of surging food prices. Agricultural Economics 2008;39:375-91.

46. Headey D. Rethinking the global food crisis: The role of trade shocks. Food Policy 2011;36:136-46.

47. FAO. FAO Food Price Index. Rome. 2016 http://www.fao.org/ worldfoodsituation/foodpricesindex/en/.

48. Messer E, Cohen MJ. Understanding and responding to the links between conflict and hunger. Dev Pract 2011;21:481-7.

49. Fao I, Unctad W. Price Volatility in Food and Agricultural Markets: Policy Responses. Rome, Italy: Food and Agricultural Organization, 2011.

50. Mittal A. The 2008 food price crisis: rethinking food security policies: UN, 2009.

51. Von Braun J, Ahmed A, Asenso-Okyere K, et al. High food prices: the what, who, and how of proposed policy actions. Washington, DC: International Food Policy Research Institute, 2008.

52. WHO. Closing the gap in a generation: Health equity through action on the social determinants of health. Geneva: WHO, 2008.

53. Morris SS, Cogill B, Uauy R. Maternal and Child Undernutrition Study Group. Effective international action against undernutrition: why has it proven so difficult and what can be done to accelerate progress? Lancet 2008;371:608-21.

54. SUN. The history of the SUN Movement: Scaling Up Nutrition. 2018 http://scalingupnutrition.org/about-sun/the-history-of-the-sunmovement/.

55. WHO. Nutrition Landscape Information System (NLIS) country profile indicators: interpretation guide. Geneva: WHO, 2012.

56. REACH. REACH Country Facilitator Manual. 2nd ed, 2013.

57. Richter J. Conflicts of interest and global health and nutrition governance: The illusion of robust principles. BMJ 2015.

58. Times of India. Activists: Don't join SUN, a nutrition drive. 2017 https://timesofindia.indiatimes.com/india/activists-dont-join-sun-anutrition-drive/articleshow $/ 58816008 . \mathrm{cms}$.

59. Lang T, Barling D. Nutrition and sustainability: an emerging food policy discourse. Proc Nutr Soc 2013;72:1-12. 
60. Cannon G. Nutrition: the new world disorder. Asia Pac J Clin Nutr 2002;11(s3):S498-509.

61. Haddad L, Martorell R. Feeding the world in the coming decades requires improvements in investment, technology and institutions. $J$ Nutr 2002;132:3435S-6.

62. Walley J, Lawn JE, Tinker A, et al. Primary health care: making Alma-Ata a reality. Lancet 2008;372:1001-7.

63. Solomons NW. Ethical consequences for professionals from the globalization of food, nutrition and health. Asia Pac J Clin Nutr 2002;11(s3):S653-65.

64. Forsyth S. Three decades of the WHO code and marketing of infant formulas. Curr Opin Clin Nutr Metab Care 2012;15:273-7.

65. Forsyth S. Non-compliance with the International Code of Marketing of Breast Milk Substitutes is not confined to the infant formula industry. J Public Health 2013;35:185-90.

66. Von Massow F. "We are forgotten on earth": international development targets, poverty, and gender in Ethiopia. Gend Dev 2000;8:45-54.

67. IRIN. Nutrition getting the attention it deserves? $2012 \mathrm{http}: / /$ www.irinnews.org/news/2012/10/31/nutrition-getting-attention-itdeserves.

68. Starling S. GAIN gains NGO status from WHO after it severs big business ties (or does it?): Nutralngredients. $2014 \mathrm{https} / / / \mathrm{www}$. nutraingredients.com/Article/2014/01/27/GAIN-gains-NGO-statusfrom-WHO-after-it-severs-big-business-ties-or-does-it.

69. Lakshminarayanan S. Role of government in public health: Current scenario in India and future scope. J Family Community Med 2011;18:26-30.

70. Gupta A, Khaira NS. Flaws in Child Nutrition and Health Governance. Economic and Political Weekly 2008:43:17-21.

71. Haddad L. Why India needs a national nutrition strategy. BMJ 2011;343:d6687-44.

72. Bhojani U, Devedasan N, Mishra A, et al. Health system challenges in organizing quality diabetes care for urban poor in South India. PLoS One 2014;9:e106522.

73. Siddiqi S, Haq IU, Ghaffar A, et al. Pakistan's maternal and child health policy: analysis, lessons and the way forward. Health Policy 2004;69:117-30.

74. Garcia SM, Rosenberg AA. Food security and marine capture fisheries: characteristics, trends, drivers and future perspectives. Philos Trans R Soc Lond B Biol Sci 2010;365:2869-80.

75. Freudenberg N, Atkinson S. Getting food policy on the Mayoral table: a comparison of two election cycles in New York and London. Public Health 2015;129:295-302.

76. Mejía Acosta A, Haddad L. The politics of success in the fight against malnutrition in Peru. Food Policy 2014:44:26-35.

77. Jaime PC, da Silva ACF, Gentil PC, et al. Brazilian obesity prevention and control initiatives. Obesity Reviews 2013;14(Suppl 2):88-95.

78. Kalita A, Mondal S. Role of innovative institutional structures in integrated governance. A case study of integrating health and nutrition programs in Chhattisgarh, India. $J$ Health Organ Manag 2012;26:758-77.

79. Kouam CE, Delisle H, Ebbing HJ, et al. Perspectives for integration into the local health system of community-based management of acute malnutrition in children under 5 years: a qualitative study in Bangladesh. Nutr J 2014;13:22.

80. Taylor SAJ, Perez-Ferrer C, Griffiths A, et al. Scaling up nutrition in fragile and conflict-affected states: The pivotal role of governance. Soc Sci Med 2015;126:119-27.

81. Pridmore P, Carr-Hill R. Tackling the drivers of child undernutrition in developing countries: what works and how should interventions be designed? Public Health Nutr 2011;14:688-93.

82. Kayser GL, Amjad U, Dalcanale F, et al. Drinking water quality governance: A comparative case study of Brazil, Ecuador, and Malawi. Environ Sci Policy 2015;48:186-95.

83. Giay T. Utilisation of wartime nutrition survival experiences. Asia Pacific journal of clinical nutrition 1998;7(3/4):311-3.

84. Montoya LA, Montoya I, Sánchez González OD. Lessons from collaborative governance and sociobiology theories for reinforcing sustained cooperation: a government food security case study. Public Health 2015;129:916-31.

85. Hawkes C, Ahern AL, Jebb SA. A stakeholder analysis of the perceived outcomes of developing and implementing England's obesity strategy 2008-2011. BMC Public Health 2014;14:441.

86. Haby MM, Doherty R, Welch $\mathrm{N}$, et al. Community-based interventions for obesity prevention: lessons learned by Australian policy-makers. BMC Res Notes 2012;5:20.

87. Solon FS. Good governance for nutrition in the Philippines: elements, experiences, and lessons learned. Food Nutr Bull 2006;27:343-52.
88. Ayoya MA, Heidkamp R, Ngnie-Teta I, et al. Précis of nutrition of children and women in Haiti: analyses of data from 1995 to 2012. Ann N Y Acad Sci 2014;1309:37-62.

89. Henderson J, Coveney J, Ward P, et al. Governing childhood obesity: framing regulation of fast food advertising in the Australian print media. Soc Sci Med 2009;69:1402-8.

90. Henderson J, Coveney J, Ward PR, et al. Farmers are the most trusted part of the Australian food chain: results from a national survey of consumers. Aust N Z J Public Health 2011;35:319-24.

91. Vallgårda $\mathrm{S}$, Holm L, Jensen JD. The Danish tax on saturated fat: why it did not survive. Eur J Clin Nutr 2015;69:223-6.

92. Colvin CJ, Konopka S, Chalker JC, et al. A systematic review of health system barriers and enablers for antiretroviral therapy (ART) for HIV-infected pregnant and postpartum women. PLOS One 2014:9:e108150.

93. Vélez LF, Sanitato M, Barry D, et al. The role of health systems and policy in producing behavior and social change to enhance child survival and development in low- and middle-income countries: an examination of the evidence. J Health Commun 2014;19 Suppl 1(sup1):89-121.

94. Turner R, Hawkes C, Jeff W, et al. Agriculture for improved nutrition: the current research landscape. Food Nutr Bull 2013;34:369-77.

95. Pinstrup-Andersen P, Watson DD II. Food Policy for Developing Countries: The Role of Government in Global, National, and Local Food Systems. 1 den. New York: Cornell University Press, 2011.

96. UNSCN. UN Standing Committee on Nutrition Mandate. Geneva: UNSCN, 2015.

97. Gillespie S, Haddad L, Mannar V, et al. Maternal and Child Nutrition Study Group. The politics of reducing malnutrition: building commitment and accelerating progress. Lancet 2013;382:552-69.

98. Müller A, Coitinho DC. Global nutrition: What should change? Food Nutr Bull 2011;32(2 Suppl):S56-8.

99. Sridhar D, Brolan CE, Durrani S, et al. Recent Shifts in Global Governance: Implications for the Response to Non-communicable Diseases. PLoS Med 2013;10:e1001487.

100. Smith LC, Haddad L. Reducing Child Undernutrition: Past Drivers and Priorities for the Post-MDG Era. World Dev 2015;68:180-204.

101. Asadi-Lari M, Vaez-Mahdavi MR, Faghihzadeh S, et al. Responseoriented measuring inequalities in Tehran: second round of UrbanHealth Equity Assessment and Response Tool (Urban HEART-2), concepts and framework. Med J Islam Repub Iran 2013;27:236-48.

102. Dube L, Webb P, Arora NK, et al. Agriculture, health, and wealth convergence: bridging traditional food systems and modern agribusiness solutions. Ann N Y Acad Sci 2014;1331:1-14.

103. Butler CD. Food security in the Asia-Pacific: Malthus, limits and environmental challenges. Asia Pac J Clin Nutr 2009;18:577-84

104. Pérez-Escamilla R. Can experience-based household food security scales help improve food security governance? Glob Food Sec 2012;1:120-5.

105. Mejía Acosta A, Fanzo J. Fighting maternal and child malnutrition: analysing the political and institutional determinants of delivering a national multisectoral response in six countries. Brighton, UK: Institute of Development Studies. A synthesis paper, 2012.

106. Haddad L, Mejía Acosta A, Fanzo J. Accelerating reductions in undernutrition: what can nutrition governance tell us. Brighton, UK: IDS, 2012.

107. Phillips L. Food and Globalization. Annual Review of Anthropology 2006;35:37-57.

108. Kraak VI, Swinburn B, Lawrence M, et al. An accountability framework to promote healthy food environments. Public Health Nutr 2014:17:2467-83.

109. Sacks G, Swinburn BA, Lawrence MA. A systematic policy approach to changing the food system and physical activity environments to prevent obesity. Aust New Zealand Health Policy 2008:5:13

110. Lee K. Global health promotion: how can we strengthen governance and build effective strategies? Health Promot Int 2006;21(suppl_1):42-50.

111. Lee K, Kamradt-Scott A. The multiple meanings of global health governance: a call for conceptual clarity. Global Health 2014;10:28-10.

112. Popkin B, Ng SW, Sw N. The nutrition transition in high- and low-income countries: what are the policy lessons? Agricultural Economics 2007:37:199-211.

113. Lasswell HD. Politics: Who Gets What, When, How. New York, Whittlesey House: McGraw-Hill, 1936.

114. Rousseau J-J. Du Contract Social. Amsterdam: Marc Michel Rey, 1762.

115. Locke J. Two Treatises of Government. London: Awnsham Churchill, 1690 
116. United Nations. International Covenant on Economic, Social and 